\title{
Do Limitations in Land Rights Transferability Influence Mobility Rates in Ethiopia?
}

\author{
Alan de Brauw and Valerie Mueller \\ Development Strategy and Governance Division, International Food Policy Research Institute- \\ Ethiopia Strategy Support Program II, Ethiopia
}

Ethiopia Strategy Support Program II (ESSP-II)

ESSP II Working Paper No. 018

March 2011

IFPRI-ADDIS ABABA

P.O. Box 5689

Addis Ababa, Ethiopia

Tel: +251-11-646-2921

Fax: +251-11-646-2318

E-mail: ifpri-addis@cgiar.org
IFPRI HEADQUARTERS

International Food Policy Research Institute

2033 K Street, NW • Washington, DC 20006-1002

USA

Tel: +1-202-862-5600

Skype: IFPRIhomeoffice

Fax: +1-202-467-4439

E-mail: ifpri@cgiar.org

www.ifpri.org 


\title{
THE ETHIOPIA STRATEGY SUPPORT PROGRAM (ESSP) WORKING PAPERS
}

\begin{abstract}
ABOUT ESSP II
The Ethiopia Strategy Support Program is an initiative to strengthen evidence-based policymaking in Ethiopia in the areas of rural and agricultural development. Facilitated by the International Food Policy Research Institute (IFPRI), ESSP works closely with the government of Ethiopia, the Ethiopian Development Research Institute (EDRI), and other development partners to provide information relevant for the design and implementation of Ethiopia's agricultural and rural development strategies. For more information, see http://www.ifpri.org/book-757/ourwork/program/ethiopia-strategy-supportprogram or http://www.edri.org.et/.
\end{abstract}

\section{ABOUT THESE WORKING PAPERS}

The Ethiopia Strategy Support Program (ESSP II) Working Papers contain preliminary material and research results from IFPRI and/or its partners in Ethiopia. The papers are not subject to a formal peer review. They are circulated in order to stimulate discussion and critical comment. The opinions are those of the authors and do not necessarily reflect those of their home institutions or supporting organizations.

\section{About the Author(s)}

Alan de Brauw, Markets, Trade and Institutions Division, International Food Policy Research Institute

Valerie Mueller, Development Strategy and Governance Division, International Food Policy Research Institute 


\title{
Do Limitations in Land Rights Transferability Influence Mobility Rates in Ethiopia?
}

\author{
Alan de Brauw and Valerie Mueller \\ Development Strategy and Governance Division, International Food Policy Research Institute - \\ Ethiopia Strategy Support Program II, Ethiopia
}




\section{Table of Contents}

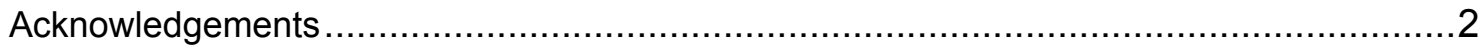

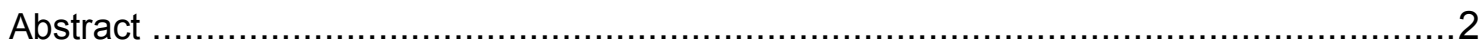

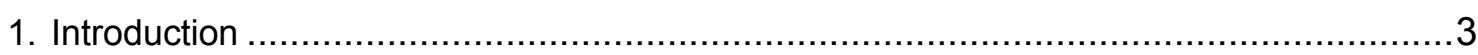

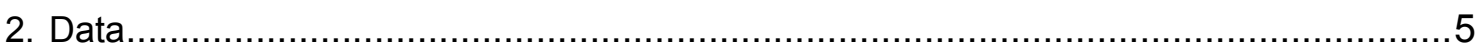

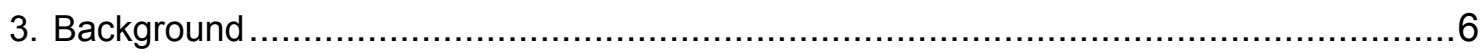

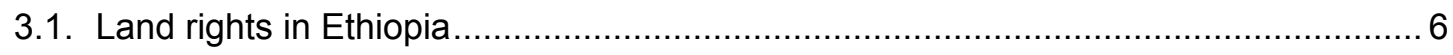

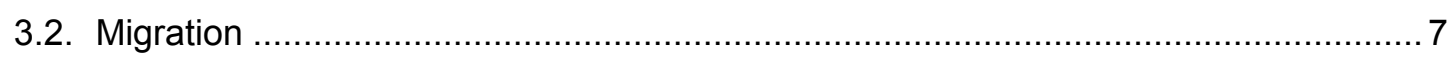

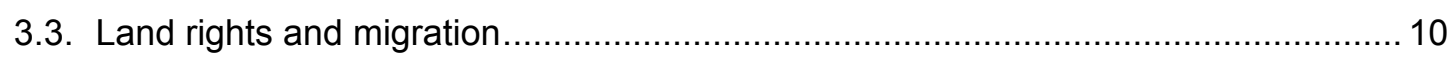

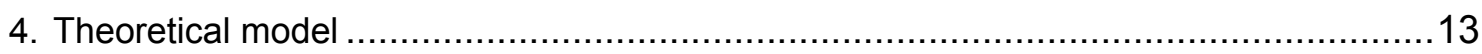

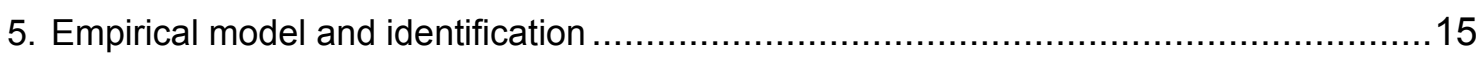

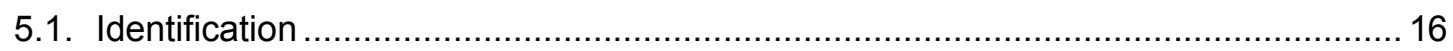

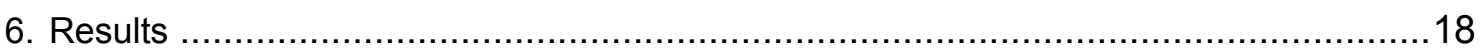

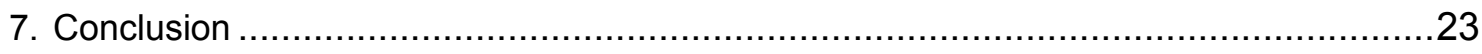

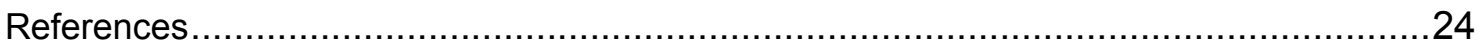

\section{List of Tables}

Table 3.1. Characteristics of households by year and migration status ............................. 8

Table 3.2. Change in migrant stock and regional heterogeneity in land availability and transferability

Table 6.1. OLS and 2SLS estimation of migration of all household members and land relationship 18

Table 6.2. OLS and 2SLS estimation of migration of all household members at least 15 years old and land relationship............................................................... 19

Table 6.3. First stage OLS regression of the share of transferable land ........................... 20

Table 6.4. OLS and 2SLS estimation of migration and land relationship differentiating

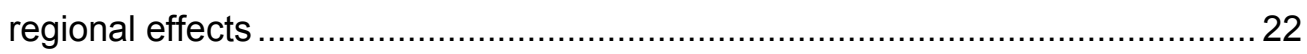

\section{List of Figures}

Figure 3.1. Percent of households with at least one migrant, by village, ERHS 9 


\title{
Acknowledgements
}

We thank Stefan Dercon, John Hoddinott, Neha Kumar, Yisehac Yohannes, and participants of the ERHS Lalibela workshop for their helpful input.

\begin{abstract}
Migration is considered a pathway out of poverty for many rural households in developing countries. National policies can discourage households from exploiting external employment opportunities through the distortion of capital markets. Studies in China show that the presence of state and collectively owned land creates inefficiencies in the labor market. We examine the extent restrictions on land rights impede mobility in Ethiopia. The empirical estimates support a modest, negative effect from increasing the transferability of land rights on migration. These findings suggest the absence of land rights slightly encourages migration. Moreover, this behavior is consistent with earlier findings which show land rights improvements encourage productivity investments assuming land and on-farm labor are complementary inputs.
\end{abstract}




\section{Introduction}

The migration of household members is potentially an attractive pathway out of poverty for many rural households in developing countries. Such households face the challenge of maintaining or improving their livelihoods in the presence of capital market imperfections, vulnerability to climate and macroeconomic shocks, and inaccessibility to credit. For many such households, labor is their main productive asset. Access to opportunities in distant labor markets through migration can increase the earning potential of members of such households (Harris and Todaro 1970). Furthermore, if migration takes place as part of a household decisionmaking strategy, it can help the source household reduce income risks (Stark 1991, Azam and Gubert 2006), at the very least, and potentially improve the wellbeing of the entire household (de Brauw and Harigaya 2007). From the former perspective, households can diversify income risk preemptively by allocating labor spatially to areas where risks to income are not correlated with rural income shocks (Rosenzweig and Stark 1989).

Despite the potential benefits of migration through reductions in income risk or improvements in overall well-being, for several reasons households in rural areas of developing countries often do not send out migrants. Households might not have members in appropriate demographic categories, as migrants tend to be younger individuals who have not yet spent significant time farming. Households might also lack information about the potential returns to labor in distant markets. Several authors have pointed out that as information flows increase through migrant networks, migration increases (Carrington, Detragiache, and Vishnawath 1996).

An alternative reason that households might not send out migrants is that they lack complete control over their landholdings. Specifically, households might fear that if one or more members of the household were absent for a period of time, then other claimants of the land, such as the local government, might expropriate it. If land expropriation can occur without compensation, households might be dissuaded from sending out migrants for fear of signaling that they do not need all of their landholdings (Yang 1997). In several settings around the world, and particularly in some transition countries, farmers do not enjoy complete land transferability rights and may fear that the government might take land that is not being used or that officials might perceive is not being used adequately.

Ethiopia is a compelling place to study whether migration is impeded by restrictions on land rights. In the past, the government explicitly discouraged migration through population policy (National Population Policy 1993). Moreover, studies indicate that improvement in property rights augments land productivity (Dercon and Ayalew 2007, Holden et al. 2009a). But there is little evidence about how and to what extent this improvement may affect labor allocation decisions. If labor and land are complementary, then we might expect that improving land security will encourage households to retain family members on the farm. If, on the other hand, labor and land are substitutes, then improving security of land rights would potentially lead to additional family members leaving the farm.

Keeping family members at home can bear consequences on long-term livelihood and risk diversification strategies. Land scarcity remains one of the limiting factors to production, where on average a household of five subsists off of one hectare of land (World Bank 2005). Moreover, Ethiopia has one of the lowest urbanization rates in sub Saharan Africa; only 16 percent of Ethiopia's population lives in cities, whereas 36 percent of the population lives in cities in the remainder of sub Saharan Africa, (World Bank 2008). Increased internal migration to cities in Ethiopia could therefore improve overall living standards, by relaxing land constraints in rural areas, providing access to services to additional individuals, including education, and increasing income opportunities. Lastly, the frequency of droughts in Ethiopia causes uncertainty in income and potentially leads to 
underinvestment (Dercon 2004, Dercon and Christiaensen 2007). Thus, reducing the correlation between covariate shocks and total income through increasing the share of migrant earnings could potentially encourage long-term growth.

The objective of this paper is to analyze the potential impacts of land transferability rights on migration behavior in rural Ethiopia. To meet this objective, we present both theoretical and empirical results. The theoretical model captures this fear of expropriation through the impact migration has on the probability of continuing to farm the same land in the future and its associated future stream of returns, following similar studies on China (Yang 1997, Lohmar 1999, de la Rupelle et al. 2009). ${ }^{1}$ The model predicts that the impact of land security on migration depends on the interaction between the level of land tenure security and the amount of on-farm labor actually applied on the land in the present.

To test the theoretical predictions empirically, we use a unique panel data set that has been collected by Addis Ababa University, the University of Oxford, and the International Food Policy Research Institute over the past fifteen years, the Ethiopia Rural Household Survey (ERHS). The ERHS has followed the same set of households in 15 villages over 15 years. We estimate a model that explains household migration flows in the 2004 and 2009 survey rounds, using first-differencing to control for household unobserved effects. In addition to changes in land transferability, we account for demographic characteristics, wealth, spatial amenities, and shocks the household may have experienced (such as serious illness, which can inhibit migration (Giles and Mu 2007)). Finally, we also address the familiar endogeneity issue that arises from measuring the perceptions of land transferability (Dercon and Ayalew 2007) through the use of instrumental variables. Our empirical results suggest improvements in land security are negatively associated with migration behavior.

The paper proceeds as follows. The next section briefly introduces the data set we will use for analysis and defines the way we will study both migration and land transferability rights. The third section provides some background on migration, land rights, and potential interactions between the two in Ethiopia. The following section presents our theoretical model, and the fifth section presents an empirical model consistent with the theory, including a discussion of identification. The sixth section describes the data set in more detail and presents results from the empirical model. The last section concludes with policy messages arising from the discussion of the results.

\footnotetext{
${ }^{1}$ Studies have noted other components comprising the opportunity cost of migrating, such as its insurance value (Binswanger and Rosenzweig 1986) or access to other benefits from land which we do not explicitly address. Although we do not focus on these factors directly we essentially control for these effects in our empirical model.
} 


\section{Data}

We use a unique panel data set that was collected between 1994 and 2009 by Addis Ababa University, the University of Oxford, and the International Food Policy Research Institute, the Ethiopia Rural Household Survey (ERHS). The ERHS has followed the same set of households in 15 rural Ethiopian villages over seven survey rounds, the latest two rounds occurring in 2004 and 2009. The survey is not geographically concentrated and includes villages in all of Ethiopia's major regions. As a result, the ERHS has been used to study many aspects of the rural Ethiopian economy, including poverty dynamics and shocks (Dercon 2004) and intrahousehold resource allocation (Dercon and Krishnan 2000). We primarily draw on the past two rounds, as they include rich, consistent sets of questions about land holdings and land transferability rights. ${ }^{2}$ We therefore also focus on explaining the change in migration behavior in 2004 and 2009, using the 1994 round to construct pre-migration household variables. This sample includes approximately 1,200 households.

To measure transferability rights, we follow Dercon and Alayew (2007) and use the share of land held by the household perceived to be transferable. As we discuss shortly, land in Ethiopia is owned and allocated by the state and historical episodes of redistribution likely affect perceptions of land rights. Although land sales are prohibited, a modest portion of the sample reported having purchased land (5.34 percent) in 2004 and fewer in 2009 (4.75 percent). There was also a small percentage of households that claimed to rent land in 2004 (5.34 percent), which slightly increased in 2009 (6.79 percent). The dominant trend with respect to land exchanges was in the form of sharecropping arrangements where 15.01 and 17.90 percent of households had some sharecropped land in 2004 and 2009, respectively. The extent of these transactions depended on the region. For example, there were no documented land purchases in our sample of households in Tigray and only one household reported renting land. Sharecropping rates in Tigray were also below the average for the rest of Ethiopia (4.69 and 9.23 percent of households in 2004 and 2009, respectively). Yet, households in the region still report high average shares of transferable land (0.58 and 0.93 in 2004 and 2009). Such regional heterogeneity suggests that land transferability may be a more suitable proxy for land security from an econometric perspective. However, it is likely that variations in informal land practices are highly collinear with perceptions of transferability. We attempt to exploit the existence of variation in land market transactions to later explain variation in perceptions of land transferability using instrumental variables.

The focus of our study is to understand whether long-term labor migration patterns change in response to land availability and land security. We identify a migrant household based on the following two conditions. First, migrants are individuals who were present in the household in the previous round of the survey (five years prior to the survey) but not present in the current round, excluding household members that died. Second, we further limit migrants to only include individuals who were at least fifteen years of age when they moved (to rule out children leaving for school). ${ }^{3}$ We present results assuming the first condition and the first and second conditions simultaneously. In regressions, our measures of migration are: 1) the number of migrants who have left since the previous survey round and 2) the number of migrants who have left since the previous round and were at least fifteen years of age when they moved.

\footnotetext{
${ }^{2}$ We focus on the latest two rounds because the survey questions that pertain to the perceptions of land transferability are similar. In the 2004 and 2009 rounds, the question is phrased, "Does anyone in the household have the right to transfer this land to someone else?" A follow-up question asks to whom the land can be transferred (anyone, only to child of head of household, only to other relative, and other). In earlier rounds, however, the questions are phrased differently which may lead to measurement error. For example, the 1999 round asks, "Does anyone in the household have the right to give away this land to another family member?"

${ }^{3}$ We attempted to impose a third condition of including migrants where the respondent noted that he/she left the household to seek employment, rather than for other reasons. This greatly reduces the sample of households due to the number of observations missing information on the motivation for migration.
} 


\section{Background}

In this section, we provide further background about the Ethiopian context. We describe land rights in some detail, and the evidence describing the effects of land rights on other outcomes that have been found in the literature. Next, we provide additional description of migration in the ERHS households. We conclude with a description of patterns in the data relating migration to landholdings and land transferability rights.

\subsection{Land rights in Ethiopia}

Land in Ethiopia is property of the state. Committees within the peasant association, a local administrative unit having one or a few villages, appropriate use rights to households for a given amount of land. The conditions for continued use of the land vary, yet there are commonalities across regions. For example, farmers must cultivate the land without interruption, remain a resident of the kebele (the weight placed on being a resident and duration of residency required for land varies), and take "proper care" of the land (Rahmato 2008). The amount of land allocated to a household is often based on historical agreements determined in most cases by household size. For example, in Adele Keke (an ERHS village in the Oromia region), two hectares of land was granted per each head upon receipt of a small fee (20 Birr) (Gashaw et al. 1996).

In the past, fear of land expropriation was a real concern. During the Derg, land redistributions were frequent with some locales experiencing as many as three rounds over ten to twelve years (Rahmato 2008). Redistributions have not been as common under the present government. In 1991, households were granted permanent use rights over land (Benin and Pender 2009). Yet redistributions still occur, although they are less common. Benin and Pender (2009) find numerous cases of redistributions occurring in the late 1990s. In their survey, $73 \%$ of the villages in Amhara experienced on average three land redistributions since 1991. Ultimately, there are key players in local governments that can decide to expropriate land for a variety of reasons, including expansion of government offices, environmental degradation, and urban development, offering a predetermined compensation to the households in exchange.

Since the Derg regime, increased security in the use right of the land has manifested in the form of land transfers mainly to family members. In most cases, those that inherit the land must be residents of the kebele. There are limited options to rent out the land, however, as regional conditions are often imposed in terms of to whom the land may be rented to, what portion of the land can be rented, what the land may be used for, and the duration of the rental contract. For example, Rahmato (2008) notes Oromia law prohibits households from renting out over half of their allocated land. Despite these available mechanisms, it is still forbidden by national law to sell, mortgage, or exchange land in Ethiopia.

The government recently has attempted to improve land security more formally through various land registration and certification programs. According to Rahmato (2008), over half of rural households have their land registered and possess user certificates. Land certificates serve two purposes: 1) to secure the right to compensation if land is reallocated and 2) to secure the right to the land during disputes (Rahmato 2008). In their survey of Ethiopia's land certification program, Deininger et al. (2008) study the extent that the registration process is equitable (in terms of existing biases against women and poor) and beneficial (using various measures of benefits and documenting the costs of first-time registration). Their preliminary evidence finds a lack of wealth and gender bias. In addition, land certification yields net benefits in the form of high demand for certification, reduced unsettled disputes, and increased investments in the short term. 


\subsection{Migration}

As previously mentioned, internal migration is thought to be relatively rare in Ethiopia. By the second definition of migrant households provided in the data section, however, we find that 72 percent of households can be considered migrant households in the ERHS. In other words, between 1999 and 2009 at least one individual aged fifteen years or more left 72 percent of households in the sample and was not found in a subsequent round of the survey. This number might seem like a significant proportion of the sample, but the period of study is relatively long and this definition includes all forms of migration, including marriage-related, employment-driven, and other reasons. ${ }^{4}$ Just under half of the individuals identified as migrants are male, and about three-fourths go to other rural destinations.

Although the average incidence of migrant households is 72 percent in the ERHS, there is some heterogeneity by site (Figure 3.1 ).

A few villages have lower migration rates with around sixty percent of households being migrant households. On the other hand, more than 80 percent of households in Dinki and Imdibir are migrant households, meaning that at least one household member aged fifteen years or more left between 1999 and 2009. The general pattern shown here is consistent with earlier sociological evidence, which showed that those two villages historically engaged in migration and had households that were prone to being landless (Kenaw and Tegegne 1996, Molla and Feleke 1996).

To investigate possible determinants of migration at the household level, we next compare household characteristics among migrant and non-migrant households in the 2004 and 2009 rounds (Table 3.1). Migrant households appear to be richer in terms of land holdings (row 1); however, their holdings have grown less over time. Demographic characteristics are also important in determining which households are migrant households. Not surprisingly, the size of migrant households grows less over time (rows 4 and 5). Additionally, migrant households tend to have older and less educated household heads prior to 2004, with slightly different ethnic backgrounds. These descriptive statistics suggest that wealth and household demographics may be key determinants of migration.

\footnotetext{
${ }^{4}$ The percent of migrant households is reduced substantially ( 41 percent) when further restricting the migrant definition to those who moved for employment. However, this figure is skewed by the high missing response rate.
} 
Table 3.1. Characteristics of households by year and migration status

\begin{tabular}{|c|c|c|c|c|c|}
\hline & \multicolumn{2}{|c|}{ Non-migrant households } & \multicolumn{2}{|c|}{ Migrant households } & \multirow{3}{*}{$\begin{array}{l}\text { T test } \\
\text { Diff. in } \\
\text { Change in } \\
\text { variable } \\
\text { means }=0^{\text {a }}\end{array}$} \\
\hline & 2009 & 2004 & 2009 & 2004 & \\
\hline & $\begin{array}{l}\text { Mean } \\
\text { (Std. Dev.) }\end{array}$ & $\begin{array}{l}\text { Mean } \\
\text { (Std. Dev.) }\end{array}$ & $\begin{array}{l}\text { Mean } \\
\text { (Std. Dev.) }\end{array}$ & $\begin{array}{l}\text { Mean } \\
\text { (Std. Dev.) }\end{array}$ & \\
\hline \multicolumn{6}{|l|}{ Land variables } \\
\hline \multirow[t]{2}{*}{ Allocated and inherited land } & 1.35 & 1.21 & 1.42 & 1.41 & $1.83^{*}$ \\
\hline & $(1.18)$ & $(0.97)$ & $(1.34)$ & $(1.42)$ & \\
\hline \multirow{2}{*}{$\begin{array}{l}\text { Share of transferable allocated } \\
\text { and inherited land }\end{array}$} & 0.86 & 0.70 & 0.87 & 0.69 & -0.23 \\
\hline & $(0.33)$ & $(0.46)$ & $(0.33)$ & $(0.46)$ & \\
\hline \multicolumn{6}{|l|}{ Household characteristics } \\
\hline \multirow[t]{2}{*}{ Tropical livestock units } & 4.63 & 2.49 & 5.36 & 3.26 & 0.20 \\
\hline & $(4.89)$ & $(2.71)$ & $(5.87)$ & $(3.36)$ & \\
\hline \multirow[t]{2}{*}{ Number of kids (ages 6-15) } & 2.06 & 1.82 & 1.79 & 1.84 & $3.39^{* * *}$ \\
\hline & $(1.41)$ & $(1.39)$ & $(1.50)$ & $(1.51)$ & \\
\hline \multirow[t]{2}{*}{ Number of adults (ages 16-40) } & 2.16 & 1.71 & 1.94 & 1.81 & $3.98^{* * *}$ \\
\hline & $(1.25)$ & $(1.00)$ & $(1.29)$ & $(1.27)$ & \\
\hline \multicolumn{6}{|l|}{ Pre-migration characteristics (1994) } \\
\hline \multirow[t]{2}{*}{ Head of household's age } & 40.96 & & 47.39 & & $-6.52^{* * *}$ \\
\hline & $(15.96)$ & & $(14.94)$ & & \\
\hline \multirow[t]{2}{*}{ Female head of household } & 0.21 & & 0.18 & & 1.24 \\
\hline & $(0.41)$ & & $(0.38)$ & & \\
\hline \multirow[t]{2}{*}{ Literate head of household } & 0.23 & & 0.15 & & $3.17^{* * *}$ \\
\hline & $(0.42)$ & & $(0.36)$ & & \\
\hline \multirow[t]{2}{*}{ Head of household is Ahmara } & 0.34 & & 0.28 & & $1.82^{*}$ \\
\hline & $(0.47)$ & & $(0.45)$ & & \\
\hline \multirow[t]{2}{*}{ Head of household is Oromo } & 0.22 & & 0.23 & & -0.17 \\
\hline & $(0.42)$ & & $(0.42)$ & & \\
\hline \multirow[t]{2}{*}{ Head of household is Tigrawai } & 0.13 & & 0.12 & & 0.45 \\
\hline & $(0.33)$ & & $(0.32)$ & & \\
\hline \multirow[t]{2}{*}{ Head of household is Gurage } & 0.03 & & 0.06 & & $-2.20^{* *}$ \\
\hline & $(0.16)$ & & $(0.24)$ & & \\
\hline \multirow[t]{2}{*}{ Head of household is Gedeo } & 0.11 & & 0.06 & & $1.86^{*}$ \\
\hline & $(0.31)$ & & $(0.24)$ & & \\
\hline \multirow[t]{2}{*}{ Head of household is Gamo } & 0.05 & & 0.04 & & 0.35 \\
\hline & $(0.21)$ & & $(0.20)$ & & \\
\hline Number of households & 332 & & 843 & & \\
\hline
\end{tabular}

Notes: Neighborhood-clustered standard errors used in the $t$ statistic calculations.

${ }^{* * *} p<0.01,{ }^{* *} p<0.05,{ }^{*} p<0.1$

${ }^{a}$ We test difference in variable mean levels for pre-migration characteristics variables. 
Figure 3.1. Percent of households with at least one migrant, by village, ERHS

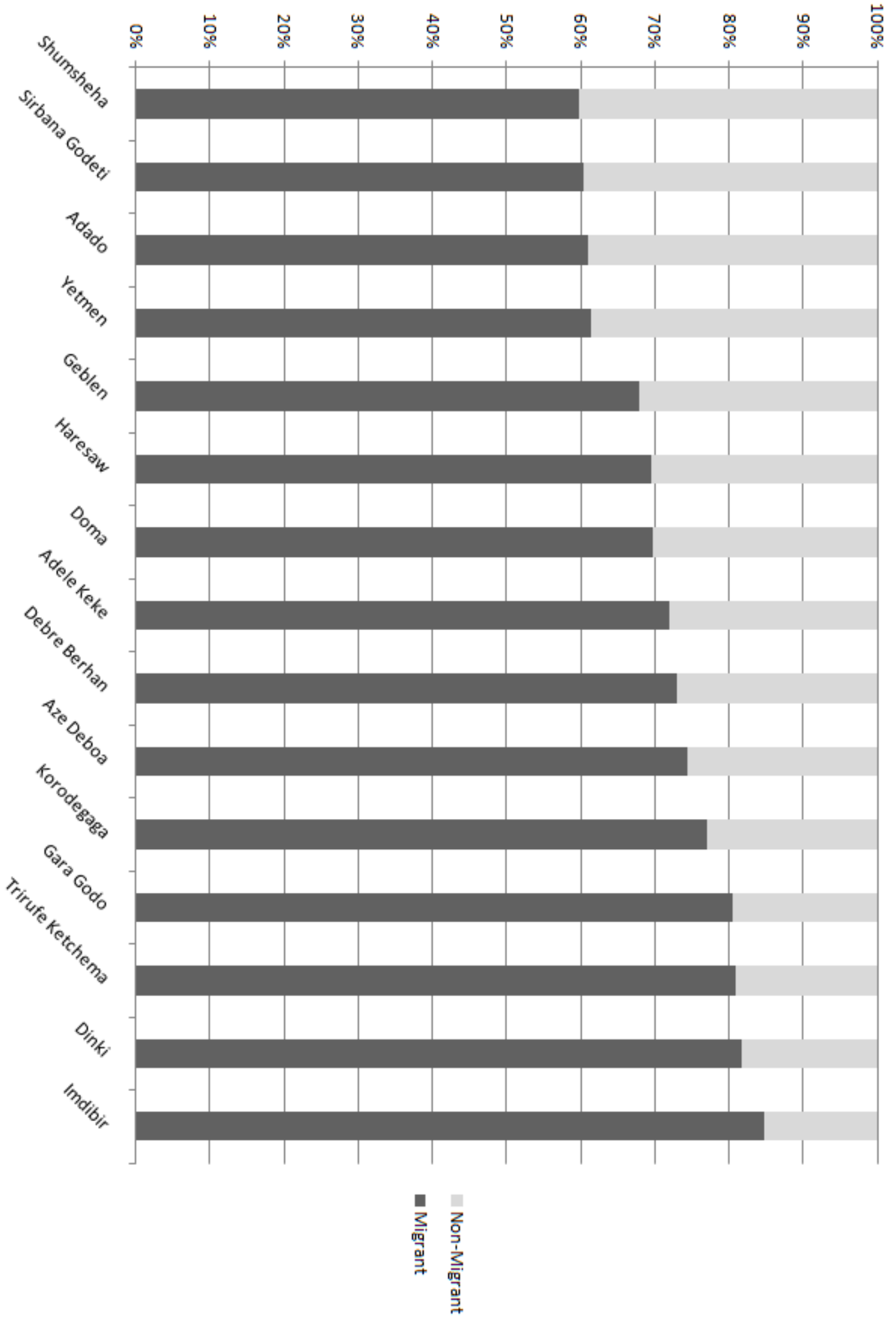




\subsection{Land rights and migration}

While some authors have linked land rights and investments in the literature on Africa's economies (Besley 1995, Deininger and Jin 2006, Dercon and Ayalew 2007, Holden et al. 2009a), no study we are aware of has attempted to study a potential relationship between land transferability rights and migration in the African context. In fact, there are very few studies in general that have looked at the relationship between migration and land transferability. Existing studies have focused on China, which has or had a similar property rights regime over land after its economic transition began. In China, as in Ethiopia, the state is the nominal owner of all land, but since HRS reforms in China households have held use rights and rights to residual but not transfer rights. ${ }^{5}$

The few studies that have considered the potential relationship between migration and land transferability rights suggest that improved land rights facilitate migration. Yang (1997) develops an economic model that describes the explicit trade-offs a household without permanent transfer rights to the land must make upon deciding to send a migrant elsewhere. Due to the lack of formal land markets, under the potential for expropriation, the household ultimately foregoes a future stream of land earnings in farming in its decision to leave the village. Therefore land investments are discouraged, but these conditions further produce a disincentive for farmers to migrate (Yang 1997). In two more recent studies, Mullen et al. (2008) suggest that improvements in land security on both agricultural and forest land increase migration in China, while de la Rupelle et al. (2009) suggest that the seasonal or temporary nature of migration in China is due to insecurity of land rights.

In Ethiopia, it is not clear whether improvements in perceived rights of transferability over land affect migration as in China. ${ }^{6}$ By transferability rights, we mean that households perceive they can transfer the use rights and the rights to residual income from land to other households at least in the medium term, but not ownership, as the state remains the nominal owner. Previous studies in Ethiopia related to land transferability rights find positive relationships between improvements in property rights and investments related to agricultural productivity (Deininger and Jin 2006, Dercon and Ayalew 2007, Holden et al. 2009a). If on-farm labor and capital are complementary, then we might expect households to retain on farm labor with improvements in land rights. Additionally, there is some evidence that households perceive transferability as a form of enhancing the tenure security risks associated with migration. For example, questions related to tenure security risks faced by migrants were added to the 2009 round of the ERHS. Fourteen percent of households claimed that the village can take over the land irrespective of the conditions if a household migrated to the woreda capital for three years without a permanent job. Another fourteen percent of households claimed that the village can take over the land only if it has not been transferred to others. Remaining households claim that nothing happens to the land perhaps under the presumption that land is transferable.

We further compare how land availability and the share of transferable land change over time by the change in the number of household migrants at the regional level (Table 3.2). ${ }^{7}$

\footnotetext{
${ }^{5}$ See Brandt et al. (2004) for a detailed description of land rights in China up to the late 1990s.

${ }^{6}$ Ethiopia provides a unique setting to study the relationship between property rights and migration in Africa, because government policy strictly forbids land sales and is responsible for the allocation of land. There are some forms of land rental and borrowing arrangements, but they do not appear to be widespread. These conditions potentially generate fear of expropriation, as witnessed in China (Jacoby, Li and Rozelle 2002). In other African countries, the pressure on land generated markets (Holden et al. 2009b). For example, the fear of expropriation is likely less relevant in Uganda, as internal migrants are reported to acquire land through land purchases (Baland et al. 2007).

${ }^{7}$ Only 41 households in our sample have a negative change in the migrant stock due to migrants from the sixth round returning by the seventh round of the survey.
} 
Table 3.2. Change in migrant stock and regional heterogeneity in land availability and transferability

\begin{tabular}{|c|c|c|c|c|c|}
\hline & \multicolumn{2}{|l|}{$\begin{array}{l}\text { No change } \\
\text { migrant stock }\end{array}$} & \multicolumn{2}{|c|}{$\begin{array}{l}\text { Positive change } \\
\text { migrant stock }\end{array}$} & \multirow{2}{*}{$\begin{array}{c}T \text { test } \\
\text { Diff. in } \\
\text { Change in } \\
\text { variable } \\
\text { means }=0\end{array}$} \\
\hline & $\begin{array}{l}2009 \\
\text { Mean } \\
\text { (Std. Dev.) }\end{array}$ & $\begin{array}{l}2004 \\
\text { Mean } \\
\text { (Std. Dev.) }\end{array}$ & $\begin{array}{l}2009 \\
\text { Mean } \\
\text { (Std. Dev.) }\end{array}$ & $\begin{array}{l}2004 \\
\text { Mean } \\
\text { (Std. Dev.) }\end{array}$ & \\
\hline \multicolumn{6}{|l|}{ All regions } \\
\hline Allocated and inherited land & $\begin{array}{r}1.44 \\
(1.27)\end{array}$ & $\begin{array}{r}1.31 \\
(1.10)\end{array}$ & $\begin{array}{r}1.35 \\
(1.34)\end{array}$ & $\begin{array}{r}1.39 \\
(1.49)\end{array}$ & $2.15^{\text {** }}$ \\
\hline $\begin{array}{l}\text { Share of transferable allocated } \\
\text { and inherited land }\end{array}$ & $\begin{array}{r}0.88 \\
(0.31)\end{array}$ & $\begin{array}{r}0.70 \\
(0.46)\end{array}$ & $\begin{array}{r}0.85 \\
(0.69)\end{array}$ & $\begin{array}{r}0.69 \\
(0.46)\end{array}$ & 0.91 \\
\hline Households & 600 & & 534 & & \\
\hline \multicolumn{6}{|l|}{ Tigray } \\
\hline Allocated and inherited land & $\begin{array}{r}0.58 \\
(0.31)\end{array}$ & $\begin{array}{r}0.48 \\
(0.28)\end{array}$ & $\begin{array}{r}0.63 \\
(0.31)\end{array}$ & $\begin{array}{r}0.49 \\
(0.26)\end{array}$ & -0.51 \\
\hline $\begin{array}{l}\text { Share of transferable allocated } \\
\text { and inherited land }\end{array}$ & $\begin{array}{r}0.90 \\
(0.28)\end{array}$ & $\begin{array}{r}0.65 \\
(0.48)\end{array}$ & $\begin{array}{r}0.96 \\
(0.19)\end{array}$ & $\begin{array}{r}0.49 \\
(0.50)\end{array}$ & $-2.75^{\star *}$ \\
\hline Households & 68 & & 55 & & \\
\hline \multicolumn{6}{|l|}{ Amhara } \\
\hline Allocated and inherited land & $\begin{array}{r}1.83 \\
(1.20)\end{array}$ & $\begin{array}{r}1.63 \\
(1.05)\end{array}$ & $\begin{array}{r}1.88 \\
(1.32)\end{array}$ & $\begin{array}{r}1.89 \\
(1.83)\end{array}$ & 1.61 \\
\hline $\begin{array}{l}\text { Share of transferable allocated } \\
\text { and inherited land }\end{array}$ & $\begin{array}{r}0.94 \\
(0.21)\end{array}$ & $\begin{array}{r}0.80 \\
(0.40)\end{array}$ & $\begin{array}{r}0.90 \\
(0.28)\end{array}$ & $\begin{array}{r}0.81 \\
(0.38)\end{array}$ & 1.26 \\
\hline Households & 207 & & 147 & & \\
\hline \multicolumn{6}{|l|}{ Oromiya } \\
\hline Allocated and inherited land & $\begin{array}{r}1.95 \\
(1.41)\end{array}$ & $\begin{array}{r}1.87 \\
(1.22)\end{array}$ & $\begin{array}{r}1.94 \\
(1.71)\end{array}$ & $\begin{array}{r}1.97 \\
(1.57)\end{array}$ & 0.56 \\
\hline $\begin{array}{l}\text { Share of transferable allocated } \\
\text { and inherited land }\end{array}$ & $\begin{array}{r}0.83 \\
(0.38)\end{array}$ & $\begin{array}{r}0.70 \\
(0.46)\end{array}$ & $\begin{array}{r}0.78 \\
(0.41)\end{array}$ & $\begin{array}{r}0.78 \\
(0.42)\end{array}$ & $2.46^{* *}$ \\
\hline Households & 160 & & 143 & & \\
\hline \multicolumn{6}{|l|}{ SNNP } \\
\hline Allocated and inherited land & $\begin{array}{r}0.82 \\
(0.97)\end{array}$ & $\begin{array}{r}0.72 \\
(0.69)\end{array}$ & $\begin{array}{r}0.72 \\
(0.67)\end{array}$ & $\begin{array}{r}0.81 \\
(0.90)\end{array}$ & $1.86^{*}$ \\
\hline $\begin{array}{l}\text { Share of transferable allocated } \\
\text { and inherited land }\end{array}$ & $\begin{array}{r}0.86 \\
(0.35)\end{array}$ & $\begin{array}{r}0.59 \\
(0.49)\end{array}$ & $\begin{array}{r}0.82 \\
(0.38)\end{array}$ & $\begin{array}{r}0.58 \\
(0.49)\end{array}$ & 0.43 \\
\hline Households & 165 & & 189 & & \\
\hline
\end{tabular}

Notes: Neighborhood-clustered standard errors used calculating t statistics. ${ }^{* * *} p<0.01 .{ }^{* *} p<0.05,{ }^{*} p<0.1$.

Differentiating by region, we observe the growth in the share of land that farmers perceive as transferable tends to be larger among households with no change in their migrant stock in all regions, except Tigray. Contrary to published findings for China, as land security increases over time, households in the ERHS appear less inclined to increase the number of migrants. Low land holdings combined with high population densities in Tigray (the land per capita in Tigray is 0.15 compared to the sample average of 0.34 hectares per person) could explain why securing property rights raises the value of sending household members elsewhere. Although Table 3.2 might suggest that there is a negative relationship between migration and land transferability rights, we have not yet provided a theoretical justification for a potential relationship. In the next section, we develop a conceptual framework to understand how perceptions in land security may affect labor allocation decisions on and off the farm, and under what conditions land security may have 
a positive or negative effect on migration. We then control for a number of potential confounding factors in the empirical section, including regional variation in land availability and property rights. 


\section{Theoretical model}

To demonstrate how the role of land may influence migration decisions in Ethiopia, we model the problem from the perspective of the head of household. His or her primary objective is to maximize household income by choosing the amount of farm land to cultivate $A$, family labor employed on the farm $L$, and labor sent to migrate for employment elsewhere $M$. We assume that household income has three components. First, households produce a single output where $Q$ is the amount produced, $f(\cdot)$ is a well behaved production function, and the output price is normalized to one. Income from the output can therefore be written as $Q=f(L, A)$. Land sales and land rentals are both rare in most of rural Ethiopia, as are sharecropping arrangements. Therefore it is reasonable to further assume that land area is fixed in the short term, which can be reflected in the production function as $Q=f(L, \bar{A})$. The choice faced by households is therefore reduced to the amount of labor put into farming. Second, the household can send out migrant labor to earn income $w M$, where $w$ is the market wage. Migrants cannot work on the farm, so the household labor endowment must be split between migration and off-farm labor. The third source of income represents the value of future agricultural production to the household. It can be written as the discounted future return from the land $\delta p(L, S)[f(L, \bar{A})]$, where $\delta$ is the discount rate, and $S$ measures tenure security. Important here is the function $p(L, S) \in[0,1]$, which represents the probability that the household will continue to hold the land in the future. We assume that the function $p(\cdot)$ depends on the number of people cultivating the land and tenure security, increases in both arguments $\left(\frac{\partial p}{\partial L}>0, \frac{\partial p}{\partial S}>0\right)$, and that it is concave. ${ }^{8}$

The household's objective is to choose $L$ and $M$ in order to maximize the total income from these three components:

$$
\max _{L, M}(1+\delta p(L, S))[f(L, \bar{A})]+w M \text { s.t. } \bar{L} \geq L+M
$$

Essentially, the third part of income illustrates the trade-off faced by the household. The household can send household members elsewhere to generate income off the farm, at the expense of agricultural production in the present and through a decrease in tenure security for future agricultural production. Equation (1) can be further simplified by assuming that able-bodied workers are employed at all times, reducing the constrained optimization problem to:

$$
\max _{M}(1+\delta p(\bar{L}-M, S))[f(\bar{L}-M, \bar{A})]+w M
$$

\footnotetext{
${ }^{8}$ The notion that migration may reduce the probability of securing land in the future period is consistent with survey evidence. We examine whether households' previous experiences with losses in land are correlated with migration that predated the loss of land. Specifically, we estimate a regression where the dependent variable is whether the household had anyone leave in the last five years in 1994 (the first survey round) and the explanatory variables include whether the household experienced any loss of land since the first survey (using data from the 1995 third survey round), the gender, age, literacy, and ethnicity of the household head in 1994, and village dummy variables, and we find a positive coefficient on the loss of land variable of 0.01 .
} 
The solution to $M$ must satisfy the following first order condition:

$$
(1+\delta p) f_{1}+\delta p_{1} f=w .
$$

Thus, the household allocates labor efforts outside of the farm such that the discounted stream of the marginal product of migrant labor on the farm over time is equal to the wages generated off of the farm. ${ }^{9}$

Our interest is to explain whether low mobility in Ethiopia is attributable to land constraints. We will empirically test whether land shortages and/or tenure insecurity affect migration decisions. To test these hypotheses, it is informative to develop priors based on our theoretical model of how these aspects of land constraints may influence migration.

First, we totally differentiate (3) with respect to $M$ and $\bar{A}$ to determine the sign of $\frac{d M}{d \bar{A}}$ :

$$
\frac{d M}{d \bar{A}}=\frac{(1+\delta p) f_{12}+\delta p_{1} f_{2}}{(1+\delta p) f_{11}+2 \delta p_{1} f_{1}+\delta f p_{11}}<0
$$

If we assume that the objective function is well-behaved and there is an interior solution, then the denominator in (4) must be less than zero due to the concavity. If we make the additional assumption that $f_{12}>0$, then it must be that $\frac{d M}{d \bar{A}}<0$. This framework therefore suggests that an increase in the land available to farmers will marginally reduce migration efforts. In other words, if land is short then households will be more likely to send out migrants.

Next, we totally differentiate (3) with respect to $M$ and $S$ to determine the sign of $\frac{d M}{d S}$ :

$$
\frac{d M}{d S}=\frac{\delta\left[p_{2} f_{1}+p_{12} f\right]}{(1+\delta p) f_{11}+2 \delta p_{1} f_{1}+\delta f p_{11}} .
$$

The numerator in equation (5) represents the expected increase in the future marginal product of labor given an increase in land security plus an increase in the marginal probability of farm labor caused by an increase in tenure security. The sign of $\frac{d M}{d S}$ will depend on the cross derivative of the probability function $p_{12}$. If $p_{12} \geq 0$, then $\frac{d M}{d S}<0$. This expected sign is somewhat consistent with studies that have examined the relationship between property rights and investment in Ethiopia. For example, if on-farm labor and investment are complementary, then households are less likely to sacrifice on farm labor with improvements in land rights. If $p_{12}<0$, then the sign of $\frac{d M}{d S}$ is indeterminate. Therefore, we must estimate an empirical model to learn about the relationship between land tenure rights and migration in Ethiopia and to learn about the importance of that relationship relative to the relationship between land shortages and migration.

\footnotetext{
${ }^{9}$ Clearly, a "corner solution" is also possible in which the household does not send out any migrants. This solution occurs if the marginal product of labor in agriculture plus the discounted marginal product of labor in agriculture, including the marginal probability of losing land, exceed the wage rate in migration. The existence of this corner solution does not affect our primary analysis, so we do not point it out explicitly above.
} 


\section{Empirical model and identification}

To investigate the relationships between migration and land suggested by equations (4) and (5), we want to understand how existing household land holdings and land transferability rights affect the migration decision, while controlling for the household labor endowment and potentially other observables that will affect the returns to labor within the household. We can write down a simple linear model consistent with these observations as follows:

$$
M_{i j t}=\alpha_{j}+\beta_{1} A_{i j t}+\beta_{2} S_{i j t}+\beta_{3} L_{i j t}+\beta_{4} W_{i j t}+\gamma_{i j t}+\varepsilon_{i j t},
$$

where $M$ represents the migration decision of household $i$ in village $j$ at time $t, A$ represents the household land holdings, $S$ represents the household's land security, $L$ represents its labor endowment, and $W$ its wealth. The variable $\gamma_{i j}$ represents fixed unobservables about the household that cannot be measured and $\varepsilon$ is a mean zero error term. In the context of our theoretical model, our interest is to measure $\beta_{1}$ and $\beta_{2}$. The main coefficient of interest is $\beta_{2}$, which measures the effects of the perception of land transferability on migration decisions, and has an indeterminate sign in the theoretical model. Unfortunately, if we were simply to estimate equation (6) using ordinary least squares, the coefficient estimates $\hat{\beta}_{1}$ and $\hat{\beta}_{2}$ would almost certainly be biased, because we cannot measure $\gamma_{i j}$ and it is likely correlated with $A_{i j}$ and $S_{i j}$.

We therefore take advantage of the panel nature of the data set to eliminate some potential sources of bias. We first difference equation (6), which removes the fixed unobservables at the household level. We also add village fixed effects $V_{j}$, which represent differences in the growth of migration and transferability over time at the village level. The fixed effects can prevent these trends from being misinterpreted as a causal relationship. The resulting equation can be written as:

$$
\Delta M_{i j t}=\beta_{0}+\beta_{1} \Delta A_{i t}+\beta_{2} \Delta S_{i t}+\beta_{3} \Delta L_{i t}+\beta_{4} \Delta W_{i t}+\sum_{j=1}^{J} V_{j}+\Delta \varepsilon_{i t} .
$$

We measure $A$ as the total household land holdings that were either allocated by the government or inherited, under the assumption that the change in landholdings cannot be affected by the change in household behavior. ${ }^{10}$ We measure $S$ as the share of allocated and inherited land over which the household reports that it has transfer rights. ${ }^{11}$ Wealth is proxied by the value of household livestock assets and we measure household labor endowment using the number of children (ages 6-15) and the number of adults of prime working age (ages 16-40) present in the household.

Finally, we add pre-migration (1994) household characteristics, $H$, such as female headship, household head literacy, ethnicity, and age. We do so because life cycle effects may be particularly important in determining migration and also correlated with changes in transferability:

\footnotetext{
${ }^{10}$ While we cannot rule out that some households in Ethiopia receive allocated land consensually, most households in our sample report little change in allocated land over the last five years. The median (mean) value of the change in allocated land is zero (eight-hundredths of a hectare). This finding at least partially suggests that either it is difficult for households to acquire additional allocated land or they lack interest.

${ }^{11}$ We include inherited and allocated land when measuring transferability. Theoretically, migration may be more responsive to allocated land. Although we do not separate the two forms of land to simplify the identification of transferability effects on migration, technically most of the effect on the parameter will reflect the impact of allocated land since the majority of land holdings are reported to be allocated. The average (median) share of allocated land is 57 (72) percent.
} 


$$
\Delta M_{i j t}=\beta_{0}+\beta_{1} \Delta A_{i t}+\beta_{2} \Delta S_{i t}+\beta_{3} \Delta L_{i t}+\beta_{4} \Delta W_{i t}+\beta_{5} H_{i t-15}+\sum_{j=1}^{J} V_{j}+\Delta \varepsilon_{i t}
$$

In all regressions, standard errors are clustered at the neighborhood level to account for arbitrary, within neighborhood, correlation between outcomes.

\subsection{Identification}

In estimating the effects of land transferability on migration, a primary concern in equation (8) is that the changes in unobservables at the household level might affect both the changes in transferability and migration, rendering the estimated coefficient on the transferability variable biased. The potential for endogeneity is particularly relevant to our sample, since a substantive portion of the increases in transfer rights in allocated and inherited land over time cannot be explained by increases in the amount of allocated and inherited land held by households (see Tables 1 and 2). We cannot rule out that the changes in the perceptions of land rights are influenced by the changes in attitudes and preferences, which are likely not captured by household fixed effects.

In order to strengthen our case for identification, we use a two pronged strategy to attempt to identify the relationship between migration and land transferability. The instruments we use are similar to the ones employed by Dercon and Alayew (2007). Specifically, we hypothesize that measure changes in the mix of ownership types over land will only affect migration behavior through the perception of transferability rights on land acquired through allocations or inheritance. Specifically, the questionnaire asked about how each plot was acquired: through inheritance, rental, by mortgage, sharecropping, purchase, borrowing, or government allocation. We measure the change in shares held by households that were acquired through the first five categories, leaving out allocated land. As an additional potential instrument, we hypothesize that if the parent of the household head was an official in the kebele, then the household would also perceive its land rights as more secure, but this additional political power would only affect migration through perceived improvements in land transferability.

Other than potential violations of exclusion restrictions, the primary drawback of these instruments is that they may not be strong and, as such, we must be concerned about weak instrument bias (e.g. Stock and Yogo 2005). If the instruments are collectively weak, then the estimated coefficient of interest may be biased and furthermore statistical inference is unreliable using standard test statistics. A further problem is that instrumental variables estimators are higher variance than linear regression estimators (Wooldridge 2002), so if instruments are relatively weak the probability of making a Type II error increases. In the event that the instruments employed are weak, we perform additional diagnostics, such as the Anderson-Rubin (1949) and Conditional Likelihood Ratio statistics (Moreira 2003) to test that the transferability effect is valid in the second stage in the presence of weak instruments.

Our second approach is to follow the methodology used by Altonji, Elder, and Taber (2005), who demonstrate how to estimate the ratio of selection on unobservables to observables that would be necessary to fully explain a coefficient of interest in the context of program evaluation, under a set of slightly modified assumptions from standard OLS assumptions. We are interested in understanding whether the estimated relationship between migration and land transferability can plausibly be explained by unobservables. To modify their methodology for the purposes of this paper, we first re-write the equation (8), suppressing the subscripts, to distinguish between all of the observables in the model $X$ from transferable land variable $S$ : 


$$
\Delta M=\Delta X \beta+\alpha \Delta S+\Delta \varepsilon
$$

Employing parallel assumptions to those in Altonji et al., we assume that the relationship between transferability and the mean of the distribution of the unobservables is the same as the relationship between transferability and the mean of the observables, adjusting for differences in the variance of these distributions:

$$
\frac{\operatorname{Cov}(\Delta \varepsilon, \Delta S)}{\operatorname{Var}(\Delta \varepsilon)}=\frac{\operatorname{Cov}\left(\Delta X^{\prime} \beta, \Delta S\right)}{\operatorname{Var}\left(\Delta X^{\prime} \beta\right)}
$$

Consider the correlation between transferability and the observables in regression (9):

$$
\Delta S=\Delta X^{\prime} \gamma+\Delta \widetilde{S}
$$

Equations (9) and (11) yield the regression:

$$
\Delta M=\alpha \Delta \widetilde{S}_{i t}+\Delta X^{\prime}(\beta+\alpha \gamma)+\Delta \varepsilon_{i t} .
$$

The estimated bias of the transferability coefficient $\alpha$ is therefore $\frac{\operatorname{Cov}(\Delta \widetilde{S}, \Delta \varepsilon)}{\operatorname{Var}(\Delta \widetilde{S})}$. Using algebraic manipulation and condition (10), the bias can be rewritten as:

$$
\frac{\operatorname{Cov}\left(\Delta X^{\prime} \gamma, S\right)}{\operatorname{Var}\left(\Delta X^{\prime} \gamma\right)} \cdot \frac{\operatorname{Var}(\Delta \varepsilon)}{\operatorname{Var}(\Delta \widetilde{S})}
$$

To calculate the estimated bias, we first estimate the migration regression on all observables $\Delta \mathrm{X}$ excluding transferability, and save the predicted value of the outcome, $\Delta X^{\prime} \gamma$. Next, we estimate a regression of the change in transferability on the predicted value $\Delta X^{\prime} \gamma$ to get the first term in (13). The numerator and denominator of the second term in (13) are the variance of the residuals from (9) and (11). The Altonji et al. statistic is then the estimated transferability parameter from equation (8) divided by the estimated bias calculated in (13). We compute and provide the Altonji et al. statistic in our tables of results for OLS specifications in which we include all observables, which equals the estimated transferability parameter from regression (8). The implied ratio demonstrates how large the shift in unobservables would have to be in order to explain away the transferability effect. In their paper, Altonji et al. argue that if the ratio is larger than one, it is unlikely that the effect predicted by the potentially endogenous variable could be fully explained by unobservables. 


\section{Results}

We first estimate equation (8) using OLS, applying both definitions of migration (Tables 6.1 and 4 respectively, columns 1-3). Whether we define migrants as any individuals who left households between surveys (Table 6.1) or as individuals who left households and were at least 15 years old when they moved (Table 6.2), we find, that regardless of the empirical specification, there is no significant relationship between the changes in the amount of landholdings by households and the measures of migration. Although the theoretical model would suggest that additional land holdings should have a negative effect on migration, the point estimates on the land variable are not significant and are often positive. Since the land area variable does not adjust much over time, however, the negative effect of landholdings suggested by the theoretical model may simply be absorbed into the household fixed effect that is differenced away. ${ }^{12}$

Table 6.1. OLS and 2SLS estimation of migration of all household members and land relationship

\begin{tabular}{|c|c|c|c|c|}
\hline Variables & $\begin{array}{l}(1) \\
\text { OLS }\end{array}$ & $\begin{array}{c}(2) \\
\text { OLS }\end{array}$ & $\begin{array}{l}(3) \\
\text { OLS }\end{array}$ & $\begin{array}{c}(4) \\
2 S L S\end{array}$ \\
\hline \multirow[t]{2}{*}{ Change in allocated and inherited land } & -0.0221 & 0.0390 & 0.0520 & 0.0639 \\
\hline & $(0.0388)$ & $(0.0351)$ & $(0.0366)$ & $(0.0418)$ \\
\hline \multirow{2}{*}{$\begin{array}{l}\text { Change in share of transferable allocated } \\
\text { and inherited land }\end{array}$} & -0.0975 & -0.0878 & -0.0952 & -0.476 \\
\hline & $(0.0870)$ & $(0.0663)$ & $(0.0677)$ & $(0.552)$ \\
\hline \multirow[t]{2}{*}{ Change in number of kids (ages 6-15) } & & $-0.394^{* * *}$ & $-0.379^{* * *}$ & $-0.371^{* * *}$ \\
\hline & & $(0.0333)$ & $(0.0351)$ & $(0.0329)$ \\
\hline \multirow[t]{2}{*}{ Change in number of adults (ages 16-40) } & & $-0.558^{* * *}$ & $-0.557^{* * *}$ & $-0.561^{* * *}$ \\
\hline & & $(0.0314)$ & $(0.0307)$ & $(0.0324)$ \\
\hline \multirow[t]{2}{*}{ Change in tropical livestock units } & & 0.0128 & 0.0153 & 0.0158 \\
\hline & & $(0.0111)$ & $(0.0112)$ & $(0.0113)$ \\
\hline \multirow[t]{2}{*}{ Head of household's age (1994) } & & & 0.0223 & 0.0210 \\
\hline & & & $(0.0138)$ & $(0.0140)$ \\
\hline \multirow[t]{2}{*}{ Head of household's age squared (1994) } & & & -0.000129 & -0.000110 \\
\hline & & & $(0.000144)$ & $(0.000146)$ \\
\hline \multirow[t]{2}{*}{ Female head (1994) } & & & -0.0466 & -0.0637 \\
\hline & & & $(0.0870)$ & $(0.0860)$ \\
\hline \multirow[t]{2}{*}{ Literate head (1994) } & & & -0.0427 & -0.0223 \\
\hline & & & $(0.0989)$ & $(0.113)$ \\
\hline \multirow[t]{2}{*}{ Head is Oromo (1994) } & & & $0.235^{\star *}$ & $0.244^{* *}$ \\
\hline & & & $(0.119)$ & $(0.104)$ \\
\hline \multirow[t]{2}{*}{ Head is Tigrawai (1994) } & & & -0.0594 & 0.0302 \\
\hline & & & $(0.130)$ & $(0.150)$ \\
\hline \multirow[t]{2}{*}{ Head is Gurage (1994) } & & & $0.808^{*}$ & $0.831^{*}$ \\
\hline & & & $(0.424)$ & $(0.451)$ \\
\hline \multirow[t]{2}{*}{ Head is Gedeo (1994) } & & & 0.155 & 0.296 \\
\hline & & & $(0.381)$ & $(0.490)$ \\
\hline \multirow[t]{2}{*}{ Head is Gamo (1994) } & & & 0.540 & 0.334 \\
\hline & & & $(0.374)$ & $(0.513)$ \\
\hline \multirow[t]{2}{*}{ Head is other ethnicity (1994) } & & & 0.0422 & 0.0506 \\
\hline & & & $(0.155)$ & $(0.156)$ \\
\hline Village Fixed Effects & Yes & Yes & Yes & Yes \\
\hline Altonji, Elder, and Taber (2005) ratio & & & 1.17 & \\
\hline Observations & 1207 & 1187 & 1181 & 1172 \\
\hline R-squared & 0.037 & 0.370 & 0.384 & 0.364 \\
\hline
\end{tabular}

Notes: Neighborhood-clustered robust standard errors in parentheses.

${ }^{* \star *} p<0.01,{ }^{* \star} p<0.05,{ }^{*} p<0.1$.Village fixed effects included. Amhara ethnicity variable is omitted

\footnotetext{
12 The lack of significance of the land coefficient is also not caused by collinearity between the lagged change in the amount of land and the lagged change in the share of land that is considered transferable variables. The partial correlation coefficient of the two variables is 0.09 .
} 
Table 6.2. OLS and 2SLS estimation of migration of all household members at least 15 years old and land relationship

\begin{tabular}{|c|c|c|c|c|}
\hline Variables & $\begin{array}{c}(1) \\
\text { Over15 } \\
\text { OLS }\end{array}$ & $\begin{array}{c}(2) \\
\text { Over15 } \\
\text { OLS }\end{array}$ & $\begin{array}{c}(3) \\
\text { Over15 } \\
\text { OLS }\end{array}$ & $\begin{array}{c}(4) \\
\text { Over15 } \\
\text { 2SLS }\end{array}$ \\
\hline Change in allocated and inherited land & $\begin{array}{l}-0.0314 \\
(0.0365)\end{array}$ & $\begin{array}{c}0.0119 \\
(0.0336)\end{array}$ & $\begin{array}{c}0.0226 \\
(0.0342)\end{array}$ & $\begin{array}{c}0.0237 \\
(0.0375)\end{array}$ \\
\hline $\begin{array}{l}\text { Change in share of transferable allocated } \\
\text { and inherited land }\end{array}$ & $\begin{array}{l}-0.117^{*} \\
(0.0697)\end{array}$ & $\begin{array}{l}-0.120^{* *} \\
(0.0588)\end{array}$ & $\begin{array}{l}-0.126^{\star *} \\
(0.0603)\end{array}$ & $\begin{array}{r}-0.0674 \\
(0.444)\end{array}$ \\
\hline Change in number of kids (ages 6-15) & & $\begin{array}{l}-0.267^{\star * *} \\
(0.0292)\end{array}$ & $\begin{array}{l}-0.256^{\star * \star} \\
(0.0311)\end{array}$ & $\begin{array}{l}-0.257^{\star \star \star} \\
(0.0282)\end{array}$ \\
\hline Change in number of adults (ages 16-40) & & $\begin{array}{l}-0.411^{* * *} \\
(0.0328)\end{array}$ & $\begin{array}{l}-0.410^{* * *} \\
(0.0330)\end{array}$ & $\begin{array}{l}-0.409^{* * *} \\
(0.0339)\end{array}$ \\
\hline Change in tropical livestock units & & $\begin{array}{l}0.00877 \\
(0.0101)\end{array}$ & $\begin{array}{c}0.0111 \\
(0.0102)\end{array}$ & $\begin{array}{l}0.0110 \\
(0.0101)\end{array}$ \\
\hline Head of household's age (1994) & & & $\begin{array}{c}0.0186 \\
(0.0113)\end{array}$ & $\begin{array}{c}0.0187 \\
(0.0114)\end{array}$ \\
\hline Head of household's age squared (1994) & & & $\begin{array}{l}-0.000116 \\
(0.000118)\end{array}$ & $\begin{array}{l}-0.000117 \\
(0.000120)\end{array}$ \\
\hline Female head (1994) & & & $\begin{array}{l}-0.0937 \\
(0.0825)\end{array}$ & $\begin{array}{l}-0.0922 \\
(0.0832)\end{array}$ \\
\hline Literate head (1994) & & & $\begin{array}{l}-0.0598 \\
(0.0793)\end{array}$ & $\begin{array}{l}-0.0711 \\
(0.0849)\end{array}$ \\
\hline Head is Oromo (1994) & & & $\begin{array}{c}0.147 \\
(0.189)\end{array}$ & $\begin{array}{l}0.156 \\
(0.187)\end{array}$ \\
\hline Head is Tigrawai (1994) & & & $\begin{array}{l}0.0784 \\
(0.129)\end{array}$ & $\begin{array}{l}0.0734 \\
(0.160)\end{array}$ \\
\hline Head is Gurage (1994) & & & $\begin{array}{l}0.274 \\
(0.349)\end{array}$ & $\begin{array}{l}0.278 \\
(0.352)\end{array}$ \\
\hline Head is Gedeo (1994) & & & $\begin{array}{r}-0.0874 \\
(0.353)\end{array}$ & $\begin{array}{l}-0.111 \\
(0.421)\end{array}$ \\
\hline Head is Gamo (1994) & & & $\begin{array}{c}0.274 \\
(0.521)\end{array}$ & $\begin{array}{c}0.276 \\
(0.553)\end{array}$ \\
\hline Head is other ethnicity (1994) & & & $\begin{array}{l}0.0433 \\
(0.173)\end{array}$ & $\begin{array}{l}0.0418 \\
(0.174)\end{array}$ \\
\hline $\begin{array}{l}\text { Village Fixed Effects? } \\
\text { Altonji, Elder, and Taber (2005) ratio }\end{array}$ & Yes & Yes & $\begin{array}{l}\text { Yes } \\
1.50\end{array}$ & Yes \\
\hline Observations & 1201 & 1181 & 1175 & 1166 \\
\hline R-squared & 0.044 & 0.303 & 0.315 & 0.313 \\
\hline
\end{tabular}

Notes: Neighborhood-clustered robust standard errors in parentheses. ${ }^{* * *} p<0.01,{ }^{* *} p<0.05,{ }^{*} p<0.1$. Amhara ethnicity variable is omitted.

Whereas there appears to be no relationship between migration and the amount of land holdings, we find a reasonably robust, negative relationship between migration and the variable measuring land transferability (Tables 3 and 4, columns 1-3, row 2). Although the coefficient estimate is consistently negative, it is only significant at the 10 percent level when we restrict the migrants to those who were at least 15 years old at the time of move. Household members that leave the household at the age of 15 and over are more likely to have left for schooling or employment reasons, reflecting the tradeoff described in our theoretical model. ${ }^{13}$ The consistently negative coefficients suggest that as households feel that they have better transferability rights over their land, they are less inclined to send out migrants. However, this effect economically speaking is rather modest. For example, using the estimates in column 3 of Table 6.2, we find that a one standard deviation change in

\footnotetext{
${ }^{13}$ We do not further restrict the number of migrants who move for employment reasons, as a substantial fraction of our migrants are missing such information.
} 
transferability (0.533) induces less than a one standard deviation change in migration rates (1.16).

Next, we account for the endogeneity of transferability in the empirical specification. First, we present estimates of the first stage, which measures the correlation between transferability and the proposed instruments (Table 6.3).

Table 6.3. First stage OLS regression of the share of transferable land

\begin{tabular}{|c|c|c|c|c|}
\hline & $\begin{array}{c}\text { (1) } \\
\text { Left } \\
\text { General }\end{array}$ & $\begin{array}{c}\text { (2) } \\
\text { Left } \\
\text { Parsimonious }\end{array}$ & $\begin{array}{c}\text { (3) } \\
\text { Over15 } \\
\text { General }\end{array}$ & $\begin{array}{c}\text { (4) } \\
\text { Over15 } \\
\text { Parsimonious }\end{array}$ \\
\hline Change in the share of inherited land & $\begin{array}{c}0.010 \\
(0.053)\end{array}$ & & $\begin{array}{c}0.009 \\
(0.052)\end{array}$ & \\
\hline Change in the share of rented land & $\begin{array}{l}-0.220 \\
(0.170)\end{array}$ & & $\begin{array}{l}-0.222 \\
(0.170)\end{array}$ & \\
\hline Change in the share of mortgaged land & $\begin{array}{c}0.227 \\
(0.169)\end{array}$ & & $\begin{array}{c}0.221 \\
(0.167)\end{array}$ & \\
\hline Change in the share of sharecropped land & $\begin{array}{l}-0.077 \\
(0.112)\end{array}$ & & $\begin{array}{l}-0.081 \\
(0.112)\end{array}$ & \\
\hline Change in the share of purchased land & $\begin{array}{c}-0.382^{* * *} \\
(0.117)\end{array}$ & $\begin{array}{c}-0.379^{* * *} \\
(0.104)\end{array}$ & $\begin{array}{c}-0.383^{* * *} \\
(0.116)\end{array}$ & $\begin{array}{c}-0.379^{* * *} \\
(0.104)\end{array}$ \\
\hline Change in the share of borrowed land & $\begin{array}{c}-0.597^{* *} \\
(0.253)\end{array}$ & $\begin{array}{c}-0.598^{* *} \\
(0.245)\end{array}$ & $\begin{array}{c}-0.601^{* *} \\
(0.252)\end{array}$ & $\begin{array}{c}-0.600^{* *} \\
(0.244)\end{array}$ \\
\hline $\begin{array}{l}\text { Parent of household head in } 2004 \\
\text { was an official in kebele organization }\end{array}$ & $\begin{array}{l}-0.068^{*} \\
(0.036)\end{array}$ & $\begin{array}{l}-0.068^{*} \\
(0.036)\end{array}$ & $\begin{array}{l}-0.066^{*} \\
(0.036)\end{array}$ & $\begin{array}{l}-0.065^{*} \\
(0.036)\end{array}$ \\
\hline Kleibergen-Paap Wald F statistic & 5.45 & 8.54 & 5.40 & 8.46 \\
\hline Cragg-Donald Wald F statistic & 3.93 & 8.40 & 3.93 & 8.37 \\
\hline Stock and Yogo critical values size of nominal & & & & \\
\hline $15 \%$ & 17.38 & 12.83 & 17.38 & 12.83 \\
\hline $20 \%$ & 12.48 & 9.54 & 12.48 & 9.54 \\
\hline $25 \%$ & 9.93 & 7.80 & 9.93 & 7.80 \\
\hline Anderson-Rubin Wald p-value (Chi-squared) & 0.15 & 0.60 & 0.11 & 0.12 \\
\hline $\begin{array}{l}\text { Conditional LR test } p \text {-value } \\
\text { Confidence Set }\end{array}$ & $\begin{array}{c}0.40 \\
{[-1.79,0.67]}\end{array}$ & $\begin{array}{c}0.30 \\
{[-1.57,0.46]}\end{array}$ & $\begin{array}{c}0.88 \\
{[-1.16,1.06]}\end{array}$ & $\begin{array}{c}0.88 \\
{[-0.97,0.88]}\end{array}$ \\
\hline Observations & 1172 & 1172 & 1166 & 1166 \\
\hline R-squared & 0.12 & 0.12 & 0.12 & 0.12 \\
\hline
\end{tabular}

Notes: Neighborhood-clustered robust standard errors in parentheses. Village fixed effects included. ${ }^{* * *} p<0.01,{ }^{* *} p<0.05,{ }^{*} p<0.1$

We test two different sets of instruments, a full set and a parsimonious set, and present estimation results for both sets with both definitions of migration. We include changes in the share of inherited, rented, mortgaged, and sharecropped land in the full set but not the parsimonious set, because the individual coefficient estimates are not significant on any of those variables. We find that the change in the share of purchased land and the share of borrowed land have consistently estimated negative coefficients associated with them, and all are significant at the 5 percent level. We also find a negative coefficient estimate associated with whether the parent of the household head in 2004 was an official in a kebele organization, significant at the 10 percent level in all specifications. Whereas we find significant coefficient estimates in the first stage, joint tests for whether or not the instruments are strong indicate that the set of instruments are weak. Specifically, the Kleibergen-Papp and Cragg-Donald Wald tests range between 3.9 and 8.5, suggesting nominal bias between 20 and 25 percent relative to OLS. Furthermore, the IV estimator is generally of higher variance than the OLS estimator, which suggests that we might not find significant coefficients in the second stage. That said however, the Anderson-Rubin and 
Conditional Likelihood ratio tests support the effect of transferability on migration behavior despite the presence of weak instruments. ${ }^{14}$

In fact, we continue to find negative coefficient estimates on land transferability when we estimate their relationship with migration using IV regression, but the coefficients are not significant (column 4, Tables 3 and 4). In the case of the broad definition of migration, this is not surprising, as the measures were insignificant using OLS as well. With the more narrow definition, the coefficient is insignificant, but the important point is that the estimated coefficient becomes smaller and statistically insignificant.

Given the insignificant coefficient estimates using IV estimation relative to OLS, we use the Altonji, Elder, and Taber (2005) approach to measure how large the shift in unobservables would have to be in order to explain away the transferability effect. Regardless of the measure of migration, the Altonji, Elder, and Taber statistic is strongly suggestive of a negative effect of land transferability on migration, even if the magnitude is not precisely estimated here. With the broad definition of migration, the ratio is 1.16 , and with the narrow definition, it is $1.50 .{ }^{15}$ In the latter case, it implies that unobservables would have to explain 1.5 times as much variation in the data as reported observables, which would not seem possible, particularly given the good explanatory power of observables already used in the regressions. Therefore, we can conclude that additional land transferability would reduce the probability of migration in the ERHS villages.

We next explore whether the effect of land transferability on migration is heterogeneous across regions. Specifically, we differentiate the region of Tigray from the rest of the sample since, as demonstrated earlier, land transactions and transferability are quite different in Tigray than in other regions. First, we try interacting land holdings and transferability with a Tigray region dummy (Table 6.4, columns 1 and 2). The results show that land transferability continues to have a negative and statistically significant effect on both migration outcomes. But the additional coefficients on transferability in Tigray are positive, and in the case of the more narrow definition of migration, significant at the 5 percent level. In both cases, we cannot reject that the sum of the transferability coefficients (i.e., land transferability and the interacted transferability coefficients) is equal to zero, which implies that in Tigray land transferability does not affect migration.

To compare how these results fare relative to the results from an IV approach, we next remove households in Tigray from the sample and re-estimate equation (8) using OLS and 2SLS. The OLS and IV estimates are presented in columns 3-6 of Table 6.4 for both definitions of migration. The OLS estimates remain negative and slightly increase in magnitude in columns 3 and 5 , and are statistically significant at the 10 percent critical level. The IV estimate on the transferability coefficient using the number of migrants' outcome is no longer significant (column 4). However, the Anderson-Rubin and Conditional Likelihood Ratio tests support that the negative effect of transferability on migration exists. Additionally, the estimate is greater in magnitude than the OLS parameter suggesting that the OLS estimate may be a lower bound of the true parameter estimate. The coefficient on transferability using the narrow definition of migration loses significance when using IV estimation, as before (column 6). However, the Anderson-Rubin and Conditional Likelihood Ratio tests continue to support the negative effect of transferability on migration in this case, although we are unable to reach the same conclusion about the OLS estimate being a lower bound of the true estimate as the parameter value moves closer to zero.

\footnotetext{
${ }^{14}$ The Conditional Likelihood Ratio test was developed in Moreira (2003).

${ }^{15}$ The ratios are reported in column 3 of Tables 3 and 4 , respectively.
} 
Table 6.4. OLS and 2SLS estimation of migration and land relationship differentiating regional effects

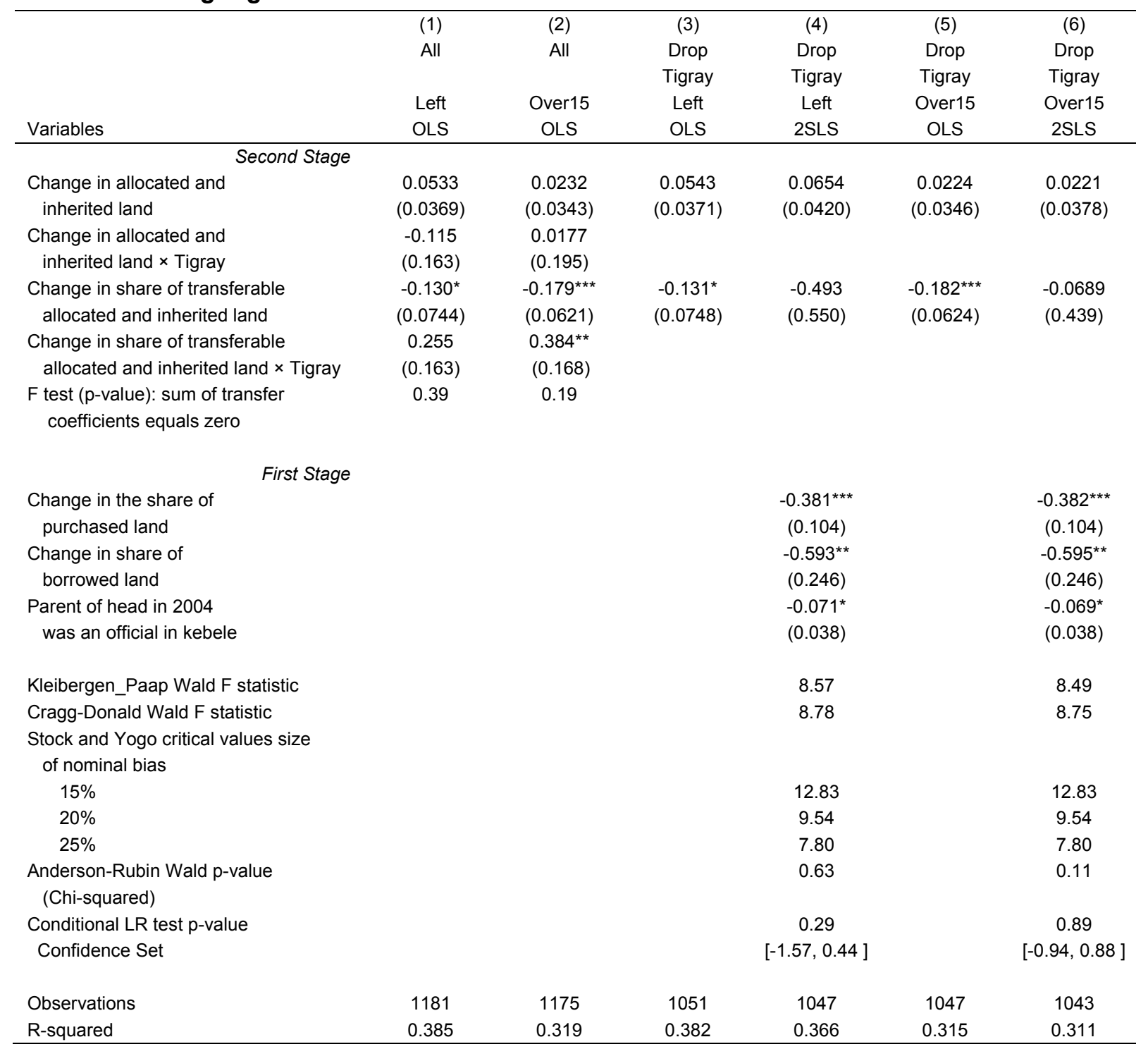

Notes: Neighborhood-clustered robust standard errors in parentheses. ${ }^{* * *} p<0.01,{ }^{* *} p<0.05,{ }^{*} p<0.1$.

In conclusion, we find that land transferability rights negatively affect migration behavior, though the magnitude of the effect is small. Although coefficient estimates using IV estimation are not statistically significant, we can rule out the possibility that our OLS estimates can fully be explained by unobservables. We also find that land transferability does not appear to affect migration in Tigray, though its removal does improve the statistical significance in the second stage of IV regression. 


\section{Conclusion}

Land in Ethiopia is nationally owned, where local governments reallocate the land periodically. It is common for households to maintain the use right of their land allotment by continuing to farm, providing adequate care to the land, and remaining a resident in the kebele (Rahmato 2008). Recent policies have promoted household land security by permitting land transfers to family members and in fewer cases to anyone. Earlier work in Ethiopia demonstrates that such improvements in land security, through increases in the households' rights to transfer land, have a positive impact on productivity-enhancing investment (Deininger and Jin 2006, Dercon and Ayalew 2007).

We offer the first study to examine how improving land transfer rights might affect household labor decisions in Ethiopia. Specifically, we evaluate the impact of land transfer rights on migration. Predictions from our theoretical model where current and future household income relies on the allocation of labor off and on the farm, the latter being also important for securing future land and farm revenue, indicate that the impact of land transfer rights will depend on the extent increasing both land and transfer rights will affect the probability of securing land in the future.

Our empirical estimates suggest improvements in land transferability rights induce a slight decrease in migration. These findings are in contrast to those found in China, where migration is induced by additional land transferability (Yang 1997, Mullen 2008). In China, the additional tenure security allows households to leave without as much fear of expropriation. In Ethiopia, it could be that the expected returns to migration are not as high as in China. Furthermore, investments in productivity can also be hindered by the lack of property rights over land, as argued in the literature on Ethiopia (Deininger and Jin 2006, Dercon and Ayalew 2007, Holden et al. 2009a). If on-farm labor and capital are complementary, improved property rights may cause households to retain on farm labor at the margin, as its marginal product increases through investments.

Although improved land transferability rights have a modest negative effect on migration, understanding the main barriers to migration in Ethiopia, particularly among impoverished agricultural households, is crucial for the development of future poverty reduction strategies. In many developing country contexts, migration can reduce vulnerability to income risk, provide access to additional sources of income, and improve overall household well-being. Thus, future research on examining the barriers and benefits of migration may shed light on viable economic alternatives for those who live below subsistence levels of well-being. 


\section{References}

Altonji, J., T. Elder, and C. Taber. 2005. Selection on Observed and Unobserved Variables: Assessing the Effectiveness of Catholic Schools. Journal of Political Economy 113 (1): 151-184.

Anderson, T., and H. Rubin. 1949. Estimation of the Parameters of a Single Equation in a Complete System of Stochastic Equations. Annals of Mathematical Statistics 20: 46-63.

Azam, J.P., and F. Gubert. 2006. Migrants' Remittances and the Household in Africa: A Review of the Evidence. Journal of African Economies 15 (2), 426-462.

Baland, J., F. Gaspart, F. Place, and J. Platteau. 2007. The Distributive Impact of Land Markets in Uganda. Economic Development and Cultural Change 55 (2): 283-312.

Benin, S., and J. Pender. 2009. Land Rental and Land Management in the Highlands of Ethiopia. Ch. 11 in The Emergence of Land Markets in Africa: Impacts on Poverty, Equity, and Efficiency, eds. S. Holden et al. Resources for the Future. Washington, D.C..

Besley, T. 1995. Property Rights and Investment Incentives: Theory and Evidence from Ghana. Journal of Political Economy 103 (5): 903-937.

Binswanger, H., and M. Rosenzweig. 1986. Behavioral and Material Determinants of Production Relations in Agriculture. Journal of Development Studies 22 (3): 503-539.

Brandt, L., S. Rozelle, and M. Turner. 2004. Local Government Behavior and Property Right Formation in Rural China. Journal of Institutional and Theoretical Economics 160 (4): 627-662.

Carrington, W., E. Detragiache, and T. Vishnawath. 1996. Migration with Endogenous Moving Costs. American Economic Review 86 (4): 909-930.

de la Rupelle, M., D. Quheng, L. Shi, and T. Vendryes. 2009. Land Rights Insecurity and Temporary Migration in China. IZA Discussion Paper no. 4668.

de Brauw, A., and T. Harigaya. 2007. Seasonal Migration and Living Standards in Vietnam. American Journal of Agricultural Economics. 89 (2): 430-447.

Deininger, K., D. Ayalew, S. Holden, and J. Zevenbergen. 2008. Rural Land Certification in Ethiopia: Process, Initial Impact, and Implications for Other African Countries. World Development 36 (10):1786-1812.

Deininger, K., and S. Jin. 2006. Tenure Security and Land-Related Investment: Evidence from Ethiopia. European Economic Review 50: 1245-1277.

Dercon, S. 2004. Growth and Shocks: Evidence from Rural Ethiopia. Journal of Development Economics 74 (2): 304-329.

Dercon, S., and D. Ayalew. 2007. Land Rights, Power and Trees in Rural Ethiopia. Discussion Paper, WPS/2007-07. CSAE.

Dercon, S., and L. Christiaensen. 2007. Consumption risk, Technology Adoption and PovertyTraps: Evidence from Ethiopia. CSAE Working Paper Series 2007-06, Centre for the Study of African Economies, University of Oxford.

Dercon, S., and P. Krishnan. 2000. In Sickness and in Health: Risk Sharing within Households in Rural Ethiopia. Journal of Political Economy 108 (4): 688-727. 
Gashaw, M., Z. Bekele, and M. Tibebe. 1996. Ethiopian Village Studies: Adele Keke. Department of Sociology, Addis Ababa University, Ethiopia and the Centre for the Study of African Economies. Oxford, UK.

Giles, J., and R. Mu. 2007. Elder Parent Health and the Migration Decision of Adult Children: Evidence from Rural China. Demography 44 (2): 265-288.

Harris, J., and M. Todaro. 1970. Migration, Unemployment, and Development: A TwoSector Analysis. American Economic Review 60 126-142.

Holden, S., K. Deininger, and H. Ghebru. 2009a. Impacts of Low Cost Land Certification on Investment and Productivity. American Journal of Agricultural Economics 91 (2) 359373.

Holden, S., K. Otsuka, and F. Place. 2009b. Land Markets and Development in Africa. Ch. 1 in The Emergence of Land Markets in Africa: Impacts on Poverty, Equity, and Efficiency, eds. S. Holden et al. Resources for the Future, Washington, D.C..

Jacoby, H., G. Li, and S. Rozelle. 2002. Hazards of Expropriation: Tenure Insecurity and Investment in Rural China. American Economic Review 92 (5): 1420-1447.

Kenaw, S., and S. Tegegne. 1996. Ethiopian Village Studies: Dinki. Eds. P. Bevan and A. Pankhurst, Department of Sociology, Addis Ababa University, Ethiopia and the Centre for the Study of African Economies, Oxford, UK.

Lohmar, B. 1999. Land Tenure Insecurity and Labour Allocation in Rural China.

Unpublished manuscript.

Molla, B., and D. Feleke. 1996. Ethiopian Village Studies: Imdibir Haya Gasha. Eds. P. Bevan and A. Pankhurst, Department of Sociology, Addis Ababa University, Ethiopia and the Centre for the Study of African Economies, Oxford, UK.

Moreira, M. 2003. A Conditional Likelihood Ratio Test for Structural Models. Econometrica, 71: 1027-1948.

Mullen, K., P. Grosjean, and A. Kontoleon. 2008. Land Tenure Arrangements and RuralUrban Migration in China. Environmental Economy and Policy Research Discussion Paper Series, Number 37. University of Cambridge, Department of Land Economy, UK.

National Population Policy. 1993. National Population Policy of Ethiopia. Online: http://cyber.law.harvard.edu/population/policies/ETHIOPIA.htm.

Rahmato, D. 2008. Ethiopia: Agriculture Policy Review. In Digest of Ethiopia's National Policies, Strategies, and Programs, ed. Taye Assefa, Forum for Social Studies.

Rosenzweig, M., and O. Stark. 1989. Consumption Smoothing, Migration, and Marriage: Evidence from Rural India. Journal of Political Economy 97 (4): 905-926.

Stark, O. 1991. The Migration of Labor. Basil Blackwell, Boston.

Stock, J., and M. Yogo. 2005. Testing for Weak Instruments in Linear IV Regression. Cambridge: Cambridge University Press.

Wooldridge, J. 2002. Econometric Analysis of Cross Section and Panel Data. Massachusetts Institute of Technology.

World Bank. 2005. Wellbeing and Poverty in Ethiopia: The Role of Agriculture and Agency. Report No. 29468-ET, World Bank, Washington, D.C. 
World Bank. 2008. World Development Indicators, CD-Rom.

Yang, D. T. 1997. China's Land Arrangements and Rural Labour Mobility. China Economic Review 8 (2): 101-115. 
INTERNATIONAL FOOD POLICY RESEARCH INSTITUTE 2033 K Street, NW | Washington, DC 20006-1002 USA $\mathrm{T}:+1.202 .862 .5600$ | F: +1.202.457.4439

Skype: ifprihomeoffice | ifpri@cgiar.org | www.ifpri.org

\section{IFPRI-ESSP ADDIS ABABA}

P.O. Box 5689, Addis Ababa, Ethiopia

$\mathrm{T}:+251.11 .617 .2000$ | F: +251.11.646.2318

mahlet.mekuria@cgiar.org | http://essp.ifpri.info
ETHIOPIAN DEVELOPMENT RESEARCH INSTITUTE

P.O. Box 2479, Addis Ababa, Ethiopia

$\mathrm{T}:$ +251.11.550.6066; +251.11.553.8633 | F: +251.11.550.5588

info@edri-eth.org | www.edri-eth.org

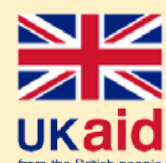

The Ethiopia Strategy Support Program (ESSP) is financially supported by the United States Agency for International Development (USAID) and UK aid from the United

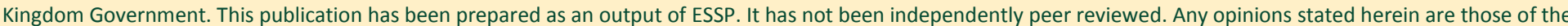

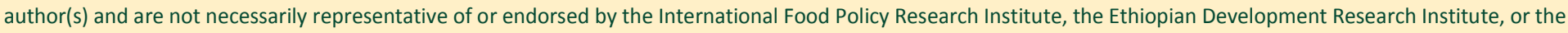
donors.

Copyright (c) 2011 International Food Policy Research Institute. All rights reserved. To obtain permission to republish, contact ifpri-copyright@cgiar.org. 